\title{
BRIGADE THOLIBAN: \\ POLITIK LOKAL SANTRI ANTARA KEPENTINGAN DAKWAH DAN TUNTUTAN EKONOMI
}

\author{
Acep Aripudin \\ UIN Sunan Gunung Djati Bandung \\ Emai: cepirfan@yahoo.com
}

\section{Abstract}

This article proves that social movements based on religious ideology of Islam is especially dynamic follow koteks socio-historical developments that occur. Response of Islamic leaders on moral concerns that plagued bis people become the main base that considers the importance of taking action as propaganda. Pure propaganda movement religious movement bas implicitly footbold in Islam. The moral movement later developed into a political movement with a target of obtaining the rights to get the role and influence in society. Penggolan Sharia law into the legal foundation of public life in Tasikmalaya district and is an important target Tholiban movement supported other Islamic organizations are congenial with Tholiban.

مسيتختلمن

يثبت هذا المقال أن الحركات الاجتماعية القائمة على الإيديولوجية الدينية للإسلام هي دينامية خاصة بعد تطور السياق الاجتماعي والتاريخي الذي يحدث. استجابة من القيادات الإسلامية الإنية

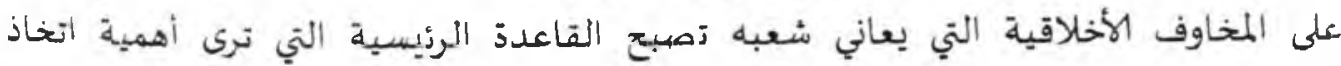

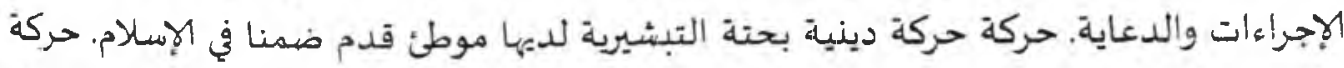

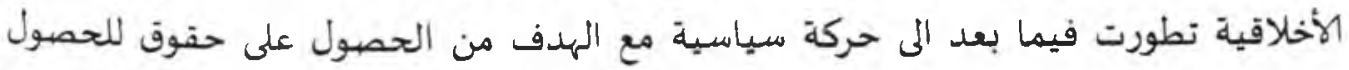

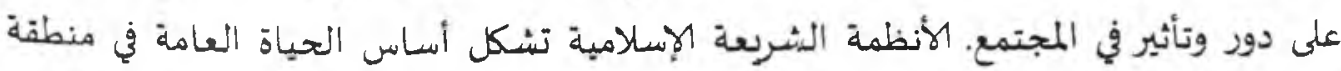

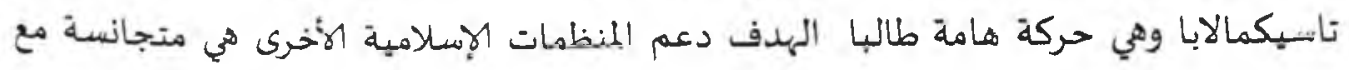
طالبا.

Keywords. da'wah, Political Santri and Brigade Tholiban. 


\section{A. Pendahuluan}

Aktualisasi kebebasan beragama dan berkeyakinan kembali bergairah setelah lama terpendam dalam kubangan tekanan penguasa Orde Lama dan Orde Baru. Gejala menggeliatnya gerakan keagamaan, baik dalam bentuk idiologi, politik maupun sparatisme, makin menampakan batang hidungnya, terutama pasca reformasi tahun 1998. Momentum reformasi telah dijadikan oleh sebagian kelompok-kelompok idiologi, termasuk idiologi berbaju agama, sebagai ekspresi atas tekanan yang dirasakan selama bertahun-tahun. Kondisi seperti itu, lebih sederhana bisa dianalogikan seperti besot yang ditekan begitu kuat sebagai bentuk dari dinamika sistem interaktif atau bentuk dialekti'sa sosial menunggu gilirannya untuk berperan lebih terbuka. Reformasi merupakan saat katup pandora dibuka dalam mengekspresikan gagasan-gagasan dan gerakan idiologis tersebut.

Fenomena dan gejala menguatnya idiologi agama terjadi bukan saja diperkotaan dimana potensi munculnya gerakan dan pemahaman idiologi agama mendapat tempat nyaman karena komplek dan berkembangnya dinamika kehidupan beragama. Gejala munculnya gerakan idiologi agama juga terjadi di daerah-daerah, baik gerakan idiologi tersebut merupakan pengembangan sayap dari gerakan idiologi agama diperkotaan maupun gerakan idiologi khas daerah tertentu yang tidak ada di daerah lain. Kelompok idiologi agama dalam Islam misalnya, kembali menggeliat di beberapa daerah di Jawa Barat, seperti Hizbut Tahrir Indonesia, Front Pembela Islam, Majlis Mujahidin dan Brigade Tholiban. Kelompok-kelompok gerakan idiologi Islam tersebut, makin berkembang dengan motivasi beragam, seperti ekonomi, politik dan dakwah. Kelompok gerakan idiologi Islam yang disebut terakhir bahkan telah menjadi patron politik pimpinan daerah seperti bupati dan walikota dan menumbukan hubungan simbiosis mutualisma. Kelompok ini diduga kuat telah menjadi kekuatan sosial dan politik lokal yang khas di Tasikmalaya, tempat tumbuh dan berkembangnya Brigade Tholiban (BT).

Beragam bentuk politik idiologi Islam yang digerakan oleh kelompok kelompok tersebut, berdasar pada sikap dan tindakan-tindakannya mengusung isu-isu perbaikan etika dan moral agama yang cenderung dilanggar oleh 
masyarakat, sehingga gerakan dan tindakan mereka masuk kategori amar ma'ruf nahi munkar' atau da'wab. Namun demikian, metode dan pendekatan dakwah mereka cenderung mengarah pada ekstrimitas yang memicu munculnya sikap pro dan kontra dalam masyarakat, terutama warga masyarakat yang memiliki pemahaman dan pendekatan Islam yang lebih lembut dan moderat.

Brigade Tholiban sebagai kelompok Islam yang tumbuh dan berkembang di Kota Santri Tasikmalaya memiliki peran penting dalam konstelasi peta dakwah dan syiar Islam, bahkan politik santri lokal hingga Nasional. Peran BT dalam ranah politik lokal telah berhasil menggolkan dan memasarkan gagasan-gagasan idiologi mereka masuk pada ranah hukum positif, seperti target-target gagasan Islam mereka agar dituangkan dalam bentuk peraturan daerah atau Perda, sehingga menjadi aturan dan rujukan hukum yang berlaku bagi masyarakat di daerahnya. Aktualisasi cita-cita gerakan Islam kelompok BT ini hingga menjadi besar, tersiar dan legal dilakukan dengan berbagai pendekatan yang potensial dalam masyarakat Tasikmalaya, seperti politik lokal, sejarah dan sentimen keagamaan.

Pengaruh gerakan Islam tranasional dan perkembangan politik domestik juga diduga memberi andil terhadap tumbuh dan berkembangnya kelompokkclompok idiologi agama di daerah sebagai akibat dari perkembanagn teknologi informasi yang masuk ke daerah-daerah. Perkembangan informasi dan konstelasi politik domestik misalnya, nampak pada gerakan dan strategi BT yang lebih politis ketika musim pemilihan umum anggota legislatif baik pusat maupun daerah. ${ }^{3}$ BT bensaha menggolkan kader-kadernya masuk pada ranah politik praktis seperti menjadi anggota dewan dengan target agar lebih mudah gagasan dan cita-cita mereka menjadi kebijakan sehingga legal, atau setidak-

\footnotetext{
'Secara bahasa artinya "menyuruh yang ma'ruf dan mencegah yang munkar" berdasar pada Quran dan Hadits. QS, 3:4.

"Secara erimologi artinya "menyeru", "memanggil" atau "mengajak". Maksudnya ialah mengajak manusia kepada Islam.

${ }^{3}$ Brigade Tholiban Tasikmalaya dicatat sudah menggolkan 1 orang wakilnya di DPR RI, 1 orang di DPRD Propinsi dan 21 orang di DPRD Kota Tasikmalaya. Ismail Hasani \& Bonar T. Najpospos, Radikalisme Agama dan Implikasinya Terbadap Kebebasan Beragama/Berkeyakinan di Jabotabek dan Jawa Barat, Wajah Para Pembela Islam, Jakarta, Pustaka Masyarakat Petras, 2010, hal.
184.
} 
tidaknya kader mereka mampu mempengaruhi arah kebijakan agar sesuai dengan cita-cita mereka.

Demokratisasi yang ditabuh rakyat Indonesia 14 tahun yang lalu memberi peluang lebih leluasa bagi kelompok seperti BT melakukan kolaborasi dan koalisi dengan pimpinan daerah atau mendukung calon pimpinan daerah dengan target bisa memperolch dukungan kebijakan yang menyokong gerakangerakannya. Namun demikian, gagasan dan gerakan mereka terbukti telah menimbulkan reaksi dari kelompok dan penganut paham Islam lainnya yang lebih mapan dan "tidak politis", seperti selama ini berkembang di pesantrenpesantren di Tasikmalaya. Reaksi kelompok mapan ini, ternyata bukan sebatas karena perbedaan pada pendekatan dan metode dakwah, dimana kelompok Islam seperti BT menggunakan metodenya lebih militan, namun juga perbedaan pada tataran pemahaman konsep etika dalam Quran dan perebutan pengaruh dalam masyarakat. ${ }^{4}$

Kelompok BT seperti dilansir beberapa media cetak maupun online telah beberapa kali melakukan tindakan penggalangan massa dan tindakan kekerasan terhadap masyarakat yang dianggapnya telah melakukan pelanggaran etika agama. Sweeping terhadap tempat-tempat hiburan malam, tempat minuman keras, penangkapan anggota msyarakat yang melakukan tindakan asusila hingga tekanan politik terhadap pemerintah setempat yang membiarkan pembangunan dan eksplorasi tambang yang dianggapnya menodai keadilan masyarakat setempat seperti terjadi di distrik Panca Tengah. Tindakan dan aksiaksi tersebut dilakukan merupakan bentuk konkrit komitmen para anggota BT terhadap nilai-nilai Islam yang harus diperjuangkan. ${ }^{5}$

${ }^{4}$ A. Aripudin, Tipologi Kejatuban Lembaga Pesantren, Studi Tiga Pesantren di Jawa Baratis Bandung, Fidkom-Lemlit Univ. Islam Negeri Sunan Gunung Djati, 2011.

SRatusan Brigade Tholiban Suarakan Aspirasi Ke DPRD Kabupaten Tasikmalaya, Task Selatan Media Online. Media Informasi Tasik Selatan. 29 Maret 2011. Sopyan Munawar, Ormas Islam Sweeping Sarang Gang Motor Brigez RMOL (Rakyat Merdeka Online)-Mingggu 18 Nopembet 2012. Masyarakat Tasikmalaya Selatan (Rampas) dan Brigade Tholiban Kembali Berdemo, DR Online 29 Maret 2011. Para Pendekar Pemberantas Kemaksiatan Bermunculan. Rahmat Blot blog.re,or.id, Eksistensi Brigade Taliban di Kab. Tasikmalaya Sebatas Dakwab Iskamiyyabal. Nuansti Post Minggu, 01 Januari 2012. 
Namun demikian, dibalik aksi-aksi dan tindakan mereka terhadap berbagai perilaku masyarakat yang dianggapnya meresahkan tersebut bukanlah satu-satunya tujuan gerakan mereka, karena bisa saja mereka juga memiliki agenda-agenda lain seperti masalah pemahaman tentang filantropi Islam dan cara-cara mengonsumsi dan mendistribusikannya. Pandangan BT tentang jihad dan cara-cara melakukannya hingga pemahaman mereka tentang masyarakat Islam lengkap dengan konsep-konsep kepemimpinan yang mesti diaktualisasikan dan diaplikasikan dalam kehidupan umat Islam. ${ }^{6}$

Pandangan sentral BT tentang "negara Islam", sepertinya merupakan salah satu gagasan sentral tentang bagaimana memelihara Islam dan umat Islam. Namun demikian guna mencapai cita-cita tersebut, seluruh komponen umat harus melakukan tahapan-tahapan sebagaimana dilakukan Rosulullah di Mekkah. Konsep "hijrah" di antara sekian konsep yang digunakan sebagai tahapan mencapai "negara Islam". Tanpa melakukan hijrah kecil kemungkinan masyarakat Islam dan negara Islam terwujud. Namun demikian, lepas dari gagasan-gagasan dan opini yang dikemukakan ke publik, kelompok BT juga tidak canggung melakukan "bargaining politik" dengan penguasa atau tokoh politik untuk mendapatkan "bantuan keuangan". Ikatan militansi massa yang kuat dijadikan alasan bahwa mereka memiliki massa yang banyak dan berepengaruh. Pctolehan keuangan mercka, sebagian kecil dibagikan kepada para anggota BT, sementara sisanya digunakan oleh pemimpin mercka untuk membangun masjid, madrasah atau majlis taklim.

Pertanyaan pentingnya berkaitan dengan peran dan eksistensi BT di Tasikmalaya ialah tentang bagaimana proses aktulisasi cita-cita kelompok BT hingga mendapat dukungan luas dari masyarakat Tasikmalaya. Bagaimana pula konsep-konsep penting yang dijadikan prioritas dalam gerakan mereka sehingga mudah diserap dan dipahami masyarakat. Konsep-konsep penting yang dikembangkannya kemudian melahirkan sebuah jaringan komunikasi yang mengatur hubungan di antara mereka dan di luar kelompoknya. Bagaimana pula keterkaitan gerakan BT secara historis dengan gerakan-gerakan Islam

${ }^{6}$ Rajiv Chandrasekaran, Indonesian Style Taliban Fights for Islamic Law, The Wshington Post, Saturday, May 4, 2002. 
sebelumnya yang pernah terjadi di Tasikmalaya. Semua pertanyaan tersebut pada akhinya akan bermuara pada sebuah pertanyaan besar hal-ihwal keberadaan BT dalam konteks gerakan Islam santri di Indonesia yang bersifat kedaerahan.

Persoalan menguatnya kembali gerakan "keagamaan lokal" seperti terjadi di Tasikmalaya tersebut menarik diungkap, karena berbagai pertanyaan terbuka maupun tersembunyi dibalik gerakan tersebut. Persoalan-persoalan mendasar nampaknya masih berputar di sekitar persoalan sumber-sumber ekonomi ekonomi dan dakwah. Potensi demikian mendapat momentumnya pada era demokrasi dan kebebasan berpolitik di Indonesia pasca reformasi. Potensi sosio-historis politik yang sudah ada sebelumnya di Tasikmalaya juga memberi sumbangan cukup kuat terhadap munculnya gerakan radikal Islam di kota santri tersebut. Dukungan masyarakat, khususnya kalangan muda produktif makin menjadi isyarat terhadap persoalan kaum muda menghadapi tantangan kehidupan yang makin komplek dan berat. Begitu besar persoalan tentang munculnya kembali gerakan keagamaan di daerah membutuhkan keseriusan dalam menanggulanginya. Luasnya bahasan dan kompleksnya persoalan diperlukan pembahasan lebih spesifik dan masuk pada jantung persoalan. Oleh karena itu, maka perlu dilakukan reduksi melalui rumusanrumusan pertanyaan, berikut: Bagaimana proses munculnya gerakan kelompok Brigade Tholiban hingga menjadi kekuatan politik massa santri berkembang di Tasikmalaya? Apa saja konsep-konsep agama yang digunakan oleh gerakan Brigade Tholiban dan perkembangannya hingga menjadi sebuah jaringan komunikasi di antara mereka dan di luar kelompoknya? Bagaimana aktulisasi gerakan-gerakan Brigade Tholiban hingga memunculkan bentuk interaksi dan dialektika dengan kelompok-kelompok Islam lainnya dan dengan pemerintah?

\section{B. Lahirnya Brigade Tholiban}

Pasca kerusuhan 1996, Tasikmalaya seperti tidak sepi dari munculnya dinamika sosial-keagamaan yang memang potensial tumbuh dalam masyarakat. Sejarah gerakan keagamaan yang bernuansa politik di Tasikmalaya pernah terjadi jauh sebelumnya, yaitu pada masa perjuangan gerakan DI/TII pada 
tahun1949 yang diproklamasikan oleh tokoh S.M. Kartosuwirjo, seorang pemuda Jawa Tengah dan kemudian menikah dengan gadis Sunda.' Gerakan lainnya ialah Komando Jihad (Komji) yang terjadi sepanjang tahun 1976-1980 di berbagai daerah, seperti Sumatera, Jawa Barat, Jawa Tengah sampai Jawa Timur. Komando Jihad digerakan oleh tokoh H. Ismail Pranoto di Sumatera, sementara di Jawa Barat digerakan oleh Warman. Berbagai tindakan dan peristiwa yang melibatkan kelompok ini, seperti teror, perampokan, pengeboman dan pembunuhan. Gerakan Komji juga terjadi di Tasikmalaya dan mereda menjelang tahun 1980 -an. ${ }^{8}$

Rentetan peristiwa gerakan Islam di atas, nampak masih sulit dihilangkan di Tatar Priangan karena berbagai fakta dan alasan yang memang sangat potensial tumbuh pada masyarakat, hingga muncul kembali pada era sekarang setelah lama ditutup secara politik pada masa Orde Lama maupun Orde Baru. Oleh karena itu, munculnya gerakan Brigade Tholiban, juga tidak bisa dilepaskan dari ikatan-ikatan sosial-historis yang ikut memelihara dan memperkuat potensi gerakan idiologi Islam yang sarat dengan gerakan politik kekuasaan. Gerakan idiologi Islam tersebut, spiritnya adalah dakwah, yaitu penyebaran dan pelaksanaan Islam dalam kehidupan masyarakat, seperti dapat dilihat dari cara dan target-target gerakannya.

Berpijak pada opini, aksi massa dan gerakannya, Brigade Tholiban lahir karena rasa cemas beberapa tokoh Islam di Tasikmalaya terhadap fenomena perilaku pclanggaran etika dan norma agama yang marak di masyarakat. Pelanggaran etika dan norma tersebut, seperti maraknya praktik perjudian, praktik prostitusi dan maraknya kebiasaan minuman keras. Belakangan kondisi tersebut meluas dengan menjamurnya kumpulan-kumpulan anak muda dalam geng-geng motor yang meresahkan masyarakat dan terakhir adalah maraknya preman-preman jalanan yang dapat memicu timbulnya pertikaian dalam masyarakat.

\footnotetext{
${ }^{7}$ Holk HAL. Dengeh, Darul Islam-NII dan Kartoswwirjo, Angan-Angan Yang Gagal, Jakarta, Sinar Harapan, 2011, hal. 1.

${ }^{8} \mathrm{M}$. Zaki Mubarak, Geneologi Islam Radikal di Indonesia; Gerakan, Pemikiran dan Prospek Demokrasi, Jakarta, LP3ES, 2008, hal. 76-77.
} 
Tepatnya pada tahun 1999 tokoh-tokoh Islam lokal, seperti Ajengan Zenzen dari Al-Irsyadiyah, Kyai Asep Mausul dari Miftahul huda dan beberapa kawannya seperti Ajengan Mubin Manonjaya di Tasikmalaya mendirikan gerakan yang disebutnya Brigade Tholiban ("barisan santri"). Agenda berdirinya B'T ini ialah pemberantasan kemaksiatan di Tasikmalaya." Brigade Tholiban Tasikmalaya, seperti diakui Ust. Ruhanudin, bahwa Gerakan Taliban Tasikmalaya tidak memiliki keterkaitannya dengan Taliban di Afganistan ataupun di Pakistan. Namun demikian prinsip ideologinya mempunyai kesamaan, juga tidak jauh berbeda dengan Ikhwanul Muslimin Mesir dan Hamas Palestina serta gerakan Islam Taliban di Afganistan. ${ }^{10}$ Perbedaannya sebagaimana yang diungkapkannya adalah dalam mengaktualisasikan tujuannya.

"Tidak seperti Taliban di Timur Tengah, sebuah organisasi besar yang sudah jauh melangkah kepada kancah politik, Taliban Tasikmalaya pergerakannya masih sebatas dakwah Islamiyyah sesuai misinya yakni "menginformasikan tentang Islam dan memperingatkan umat Islam yang telah sampai kebenaran kepadanya." Adapun obsesinya adalah mengislamkan khususnya para penguasa yang berprelikaku zalim, di mana konsep dasar dalam pencapaian tujuannya adalah berupaya menggeser keberadaan masyarakat dari kebodohan ke arah yang berpengetahuan dan berpemikiran serta berwawasan luas, sehingga akhirnya dapat diimplementasikan menjadi sebuah harapan dalam. perwujudan nyata yang dipandu oleh konsep Islam secara komprehensif. ${ }^{11}$

Ajengan Zenzen pemimpin Pesantren Al-Irsyadiyah sekarang merupakan pimpinan BT yang dikenal sangat pandai bermain politik. la tidak segan berkoalisi dengan calon walikota maupun bupati dalam menggolkan perda-perda syariah, seperti terjadi pada tahun 2007 dimana Tholiban mendukung Syarif sebagai walikota. Namun dukungan tersebut harus dibayar oleh Syarif dengan perda No. 12/2009 tentang Pembangunan Tata Nilai

'Ismail Hasani \& Bonar Tigor Najpospos (Ed), Radikalisme Agama dan Implikasinya Terhadap Jaminan Kebebasan Beragama/ Berkeyakinan di Jabidetabek dan Jawa Barat, Wajab Para Pembela Islam, Jakarta, Pustaka Masyarakat Setara, 2010, hal. 99.

${ }^{10}$ Rajiv Chandrasekaran, Indonesian-Style Taliban Fights for Islamic Law, The Washington Post, May 04, 2012.

${ }^{11}$ Nuansa Post, Membawa Aspirasi Masyarakat, 01 Januari 2012. 
Kemasyarakatan Berdasar pada Ajaran Islam dan Norma-Norma Sosial Masyarakat Tasikmalaya. ${ }^{12}$

BT mulanya merupakan Forum Silaturahmi para ajengan dan ulama dari berbagai ormas Islam di Tasikmalaya. Berselang satu tahun setelah silaturahmi itu, Tholiban didirikan, yaitu pada tahun 1999 setahun setelah terjadi reformasi di Indonesia. Setelah itu, Tholiban langsung mengukuhkan diri sebagai ormas Islam anti maksiat dan rajin melabrak berbagai perilaku maksiat, seperti perjudian, pelacuran dan peredaran minuman keras yang terjadi di Kota Tasikmalaya.

Lahirnya Tholiban di Tasikmalaya tidak bisa dilepaskan dari ruang yang sangat mendukung lahirnya gerakan ini. Situasi politik lokal dan Indonesia pada umumnya sangat menentukan bagi tercapainya target-target gerakan mereka seperti memasukan gagasan-gagasan Islam syariat menjadi peraturan positif. Kemenangan beberapa partai Islam, dan atau partai berbasis umat Islam, seperti PKB 5 kursi, PAN 3 kursi, PPP 11 kursi dan PBB 2 kursi. Kemenangan mutlak partai-partai Islam ini dimanfaatkan oleh Tholiban untuk memasukan peraturaperaturan daerah bernuansa Islam. Lebih dari itu, gerakan politik mereka juga telah berhasil menggolkan salah seorang pimpinan mereka Kyai Asep Mausul yang juga pimpinan Pesatren Miftahul Huda menjadi anggota DPR RI dari Partai PPP.'

Upaya penegakan dan penekanan syariat Islam makin terbuka lebar dilakukan Tholiban dan juga FPI (Front Pembela Islam) setelah Tatang Farhanul Hakim, ketua PPP Kabupaten Tasikmalaya menjadi bupati pada tahun 2001. Tholiban mendesakkan gagasan-gagasan Islam syariat ke dalam rencana strategis (renstra) Kabupaten Tasikmalaya yang didukung partai-partai Islam dan berhasil. Pada renstra Kabupaten Tasikmalaya 2001-2005 yang dituangkan dalam Perda No. 13/2001 disebutkan bahwa visi Kabupaten Tasikmalaya sebagai kabupaten "religious Islami sebagai pusat pertumbukan di Priangan

\footnotetext{
${ }^{12}$ Ismail Hasani \& Bonar Tigor Naipospos (Ed), Radikalisme Agama dan Implikasinya, ... ibid, hal. 183.

${ }^{13}$ Ismail Hasani \& Bonar Tigor Naipospos (Ed), Radikalisme Algama dan Implikasinya,... ibid, hal. 184.
} 
Timur serta mampu menempatkan diri menjadi kabupaten maju di Jawa Barat pada tahun 2010.

Tidak cukup di situ, realisasi dari perda di atas ialah dikeluarkannya surat edaran Bupati Tatang Farhanul Hakim yang bernuansa syariat Islam, seperti Surat Edaran No. 451/SE/Sos/2001 tentang upaya peningkatan kualitas keimanan dan ketakwaan. Visi di atas, kemudian diubah dan direvisi dengan Perda No. 13/2003 menjadi "Tasikmalaya yang Religius/Islami sebagai kabupaten yang maju dan sejahtera serta kompetitif dalam bidang agribisnis di Jawa Barat tahun 2010". 14

Eksistensi dan peran BT dari tahun ke tahun posisinya makin kuat. Jumlah anggota BT hingga sekarang berjumlah sekitar 3000 orang. Sebagaian anggota berasal dari kalangan santri Pesantren Miftahul Huda, Al-Irsyadiyah dan Nurul Jaza Tasikmalaya. Pada Pesantren Miftahul huda banyak santrinya bergabung dengan Resimen Santri (Resan) dan Tasikmalaya Solidarity of Muslim (TSM), dan santri-santri yang tergabung dalam kedua organ bagian inilah aksiaksi massa, sweeving dan tekanan politik dilakukan.

Nanun demikian, ormas BT sangat terbuka terhadap siapa saja yang ingin bergabung yang berasal bukan dari pesantrer. Jadi tidak ada perekrutan khusus, meskipun mereka diharapkan ikıt dalam pengajian Kamis malam, bulanan dan atau langsung ikut razia yang dilakukan Tholiban. Oleh karena itu, tidak mengherankan jika orang yang ikut dalamı Tholiban, rekrutmen dan motivasinya berbeda-beda, seperti karena diajak teman, mantan preman yang sudah insaf, motivasi dakwah (amar ma'muf nabi munkar), numpang beken, berlindung di balik kebesaran $B T$ maupun sekedar ingin memanfaatkan Ajengan Zezen dan Asep Mausul. ${ }^{15}$ Tokoh Asep Mausul bahkan sekarang menjadi anggota DPR RI dari faksi PPP dan berkantor di Jakarta.

${ }^{14}$ Ismail Hasani \& Bonar Tigor Naipospos (Ed), Radikalisme Agama dan Implikasinya, ... ibid, hal. 185.

${ }^{15}$ Tokoh lain yang disegani dalam Tholiban adalah Kyai Aziz Affandi adik Asep Mausul dan keduanya putra KHAL. Khoer Affandi pendiri Pesantren Miftahul Huda dan mantan tokoh di di Tasikmalaya. Ismail Hasani \& Bonar Tigor Naipospos (Ed), Radikalisme Agama dan Implikasinya, ... Ibid, hal. 187. 


\section{Aktivitas Dakwah}

Maraknya perjudian, minuman keras, perzinaan dan perilaku kriminal di Kota Tasikmalaya jelas sangat bertentangan dengan Islam. Perilaku-perilaku tersebut harus diberantas dan dibersihkan dari bumi Tasikmalaya. Sikap demikian, meskipun tujuannya sesuai dengan aspirasi Islam, namun caranya nampak sangat bertentangan dengan nilai-niai kemanusiaan dan bahkan nilainilai Islam. ${ }^{16}$ Tindakan penangkapan terhadap Pekerja Seks Komersial (PSK), teror massa, sweeping terhadap pelaku minuman keras dan geng motor yang dilakukan secara silent atau boleh dibilang bergerilya secara door to door". ${ }^{17}$ Mereka melakukan tindakan-tindakan tersebut, menyebutnya sebagai dakwah sekaligus spirit jihad yang ada dalam Islam.

BT di samping melakukan "tindakan-tindakan dakwah" dengan cara pendekatan fisik juga melakukan dakwah melalui lisan, seperti ceramah akbar, majlis taklim dan ceramah keliling. Dakwah seperti itu, meminjam istilah Yusuf Qardhawi, disebut dengan lisan al-Bayan yang dianggapnya bagian dari jihad, tepatrya al-Bayan al-Nutqi. ${ }^{18}$ Jihad dengan lisan al-Bayan ini, mengacu Qardhawi memiliki beberapa bentuk, berikut:"pertama, bayan Safabi (oral statement), seperti dalam bentuk pengajaran, perkuliahan, yang disampaikan kepada orangorang dengan bahasa dan tingkat intelektual mereka.

Kedua, bayan tasbribi (declarative statement). Yaitu, penyampaian risalah Islam melalui buku, surat, penerbitan, penelitian dan artikel yang ditujukan kepada berbagai lapisan masyarakat. Bayan tashrihi sangat selaras dengan isyarat dakwah dalam Quran "...serulah manusia ke jalan Tuhanmu dengan hikmah dan pelajaran yang baik..." ${ }^{20}$ Ketiga, bayan melalui dialog, sebagaimana isyarat terusan ayat di atas. Termasuk kategori bayan dialog adalah dialog agama dan peradaban. Keempat, bayan I'lami (press release), yaitu melakukan dakwah melalui bentuk drama, kisah, teater, sandiwara, film dan serial yang disajikan di radio,

\footnotetext{
${ }^{16} \mathrm{QS}, 16: 125$.

17Suat Kabar Umum "Nuansa Post", Membawa Aspirasi Masyarakat, Januari 2012.

17Yusuf Qadhawi, Figib Jibad, Sebuab Karya Monumental Terlengkeap Tentang jibad Menurut al Ueran dan Sunnah, tr. Irfan M. Hakim dkk, Bandung, Mizan, 2009, hal. 143.

${ }^{19}$ Yusuf Qadhawi, Figib Jihad,.......ibid, hal. 145.

200S, 16:125.
} 
televisi, bioskop, atau di gedung teater. BT juga di samping melakukan cara bayan al-Nutqi, terdengar melakukan rencana jihad dakwah melalui pendekatan sejata. Namun, pendekatan terakhir ini ditepis para pimpinan BT dan mengalihkan orientasi dakwahnya kepada cara yang lebih lunak, seperti politik praktis dan tabligh.

Dari keempat bentuk "jihad dakwah" tersebut, bayan safahi dan bayan dialog merupakan cara yang paling banyak dilakukan oleh ormas Brigade Tholiban. Bayan dialog dilakukan BT terutama dilakukan ketika berhadapan dengan pihak-pihak berwenang yang tugasnya "diambil alih" oleh BT, seperti kepolisian dan tentara serta bupati dan walikota. Sementara oral statement dipraktikan dan ditujukan khususnya kepada kalangan internal kelompok BT dan masyarakat yang bersimpati terhadap sepak-terjang gerakan yang dilakukan BT.

Munculnya Barisan Tholiban (BT) seperti disebut di muka, mulanya adalah bentuk keprihatinan mendalam terhadap maraknya praktik-praktik maksiat, seperti prostitusi, perjudian, hiburan malam, maraknya miras dan ketidak-berpihakan penguasa memberi sanksi terhadap pelanggaran-pelanggaran moral dan keadilan. Tidak seperti Taliban di Timur Tengah, Tholiban Tasikmalaya pergerakannya masih sebatas dakwah Islamiyyah. Sesuai misinya, yaitu "menginformasikan tentang Islam dan memperingatkan umat Islam yang telah sampai kebenaran kepadanya", atau dalam bahasa lain disebut da'wah.

Adapun target dakwah yang menjadi obsesi BT ini adalah mengislamkan khususnya para penguasa yang berperilaku zalim, di mana konsep dasar dalam pencapaian tujuannya adalah berupaya menggeser keberadaan masyarakat dari kebodohan ke arah yang berpengetahuan dan berpemikiran serta berwawasan luas, sehingga akhirnya dapat diimplementasikan menjadi sebuah harapan dalam perwujudan nyata yang dipandu oleh konsep Islam secara komprehensif. ${ }^{21}$

Cara yang ditempuh untuk mencapai target dakwah tersebut, antara lain dilakukan dengan ceramah dan bimbingan agama, baik terhadap kelompok kecil (da'wab fi'ab) seperti pengajian rutin mingguan, bulanan dan Tabligh Akbar yang bersifat terbuka. Penyampaian pemahaman Agama kepada masyarakat juga 
dilakukan melalui dakwah secara"door to dour". Sasaran utama cara dakwah seperti ini adalah masyarakat umum, bahkan pada waktu-waktu tertentu, BT tidak sungkan-sungkan mendatangi para penguasa setempat, seperti tokoh Agama, tokoh masyarakat hingga bupati.

Target penting lainnya dari dakwah yang dilakukan BT, terutama para penguasa pemerintahan. Kalimat Hadits Nabi "kul al-Haq walaukana murran" (sampaikan kebenaran meskipun menyulitkan), nampaknya menjadi alasan kuat sasaran penting dakwah mereka adalah penguasa zalim. Mereka punya alasan, bahwa para pemimpin khususnya di Indonesia tidak ada yang benar-benar membawa amanah, bisa dikatakan semuanya lebih dominan mementingkan diri sendiri dari pada memperhatikan kepentingan masyarakat. ${ }^{22}$ Dalam konteks ini, figur seorang pemimpin yang diharapkan dalam gerakan dakwah BT seperti Ayatullah Khomeini di Iran, begitu bersahaja dan jauh dari sifat keduniaan.

Atas dasar inilah diperlukan upaya mengimankan mereka, meskipun diakui cara demikian tidak mudah dilakukan. Taliban Tasikmalaya saat ini baru scbatas mengawasi, karena usaha mendongkrak sebuah krisis moral diperlukan adanya perpaduan pemikiran dan pemahaman yang sama dengan masyarakat. Oleh karena itu, upaya penyebaran dan intensitas kajian agama dilakukan pada hampir setiap desa yang ada tokoh tholiban. Pengajian yang diikuti oleh para orang tua dan remaja selalu menjadi perhatian dalam dakwah tholiban, di samping melakukan upaya kaderisasi massa tholiban kepada khalayak agar gagasan tholiban lebih memasyarakat, seperti dilakukan ustazd Misbah di Pagerageung.

Jaringan dakwah BT memperoleh cara relatif mudah karena mereka memiliki jaringan pesantren yang berpusat di Pesantren Miftahul Huda Manonjaya. Pesantren ini, sekarang sudah memiliki lebih dari 114 cabang dan umumnya tersebar Jawa Barat. Pesantren, jika mengacu pendapat Dhofier ${ }^{23}$ tidak hanya memiliki hubungan kekerabatan dan kekeluargaan, namun sudah membentuk semacam jaringan intelektual yang didalamnya juga mengikat

${ }^{27}$ Membawa Aspirasi Masyarakat, Nuansa Post, 1 Januari 2012.

${ }^{25}$ Zamakhsyari Dhofier, Tradisi Perantren; Studi Tentang Pandangan Hidup Kyai dan Visinya Membangun Masa Depan Indonesia, Edisi Revisi, Jakarta, LP3ES, 2011, hal. 122. 
hubungan antara guru-murid, santri-kyai sehinga membentuk rantai intelekrual (intellectual chains) yang tidak terputus. Artinya bahwa antara satu pesantren dengan pesantren lainnya, baik dalam satu kurun zaman maupun dari satu generasi ke generasi berikutnya, terjalin hubungan intelektual yang mapan hingga perubahan dalam lingkungan pesantren sebenarnya.

Pesantren Miftahul Huda yang berada di jantung Kota Tasikmalaya merupakan sentra sekaligus pusat penyebaran para santri yang kebanyakan menjadi anggota BT. Sebaran santri hampir meliputi Jawa Barat terutama daerah-daerah penyangga terdekat, seperti Garut, Ciamis dan Cianjur. Karenanya, tidak menghenrankan jika spirit gerakan seperti BT juga terjadi di daerah-daerah tersebut, terutama Garut dan Cianjur. Mereka umumnya juga membuka pesantren dan memiliki santri. Nama pesantrennya biasanya juga sama Miftahul Huda atau Nurul Huda.

Layaknya sebuah pesantren "tradisional", pengajian-pengajian rutin kitab-kitab klasik atau disebut "Kitab Kuning" yang ditentukan pengelola pesantren menjadi sumber dan metodologi pengajaran Islam. ${ }^{24}$ Namun demikian, di samping pengajaran rutin kitab-kitab klasik, pesantren juga melakukan kegiatan dakwah terhadap masyarakat luas dalam bentuk pengajian rutin kepada masyarakat terdekat di lingkungan pesantren. Pesantren sekelas Miftahul Huda di Tasikmalaya merupakan tipologi pesantren yang masih kuat mempertahankan tradisionalisme salafi, dalam arti tidak mengikuti arus modernisasi seperti membuka sekolahan.

Minat orang tua santri di 'Tasikmalaya untuk memasukan anaknya ke pesantren ini sangat kuat, meskipun Miftahul Huda kukuh mempertahankan model pesantren salafi-tradisional. Sekira 3000-an santri yang belajar di pesantren ini dan ribuan alumni tersebar di berbagai daerah menunjukan pesantren ini memiliki kharisma dalam masyarakat. Peta formal para alumni ini jelas memberi andil terhadap perkembangan jaringan intelektual pesantren sekaligus penyebaran Islam atau dakwah dan paham-paham pesantren secara efektif.

\footnotetext{
${ }^{24}$ Martin van Bruinessen, Kitab Kuning; Pesuntren dan Tarekat, Bandung, Mizan, 1993.
} 


\section{Politik BT}

Membicarakan Islam dan politik dalam konteks Indonesia, mengacu pandangan Nurcholis Madjid, melibatkan kekhawatiran dan harapan lama yang mcncekam. Daerah itu penuh ranjau kepekaan dan kerawanan, sehingga pekerjaannya harus dilakukan dengan hati-hat. ${ }^{25}$ Politik Islam seperti dicatat sejarah dalam konteks Indonesia muncul dalam bentuk dialektis dan fluktuatif. la bisa bergandengan dengan kultur dan kekuasaan, namun juga bisa berjalan secara kontradiktif, schingga memunculkan bentuk hubungan umat Islam dengan pemerintah bersifat bersebrangan, konflik, pertikaian dan pertumpahan darah, seperti pada kasus Tanjung Priok. ${ }^{2 t}$

Sejak kemerdekaan diproklamirkan, umat Islam Indonesia sudah mengambil sikap santun dan lebih mengedepankan rasa persatuan dan persaudaraan sebangsa. Namun sikap umat Islam demikian diikuti pula dengan sikap hati-hati sambil mengikuti perkembangan yang ternyata memunculkan kecenderungan-kecendurang politik yang makin tidak menentu, khususnya dalam hal pembagian "kue pembangunan", seperti pemerataan ekonomi dan kebebasan berpendapat. Persoalan tersebut, puncaknya terjadi ketika bangsa Indonesia mcmasuki babak baru yang lebih dikenal sebagai era Orde Baru. Pettumbuhan ckonomi dan pemeliharaan stabilitas politik yang tidak dibarengi dengan pemerataan hasil-hasil pembangunan telah memunculkan gejala-gejala instabilitas dan tumbuhnya perlawanan bawah tanah (underground) yang dilakukan umat Islam.

Fakta-fakta perlawanan, atau lebih tepatnya perjuangan umat Islam, guna meraih kekuasaan politik dapat dirunut sejak permulaan kemerdekaan. Persoalan yang muncul pada saat itu ialah tentang landasan apa yang akan digunakan dalam kehidupan berbangsa dan bernegara?. Perdebatan muncul meskipun pada akhirnya disepakati dengan Pancasila dan UUD 1945 sebagai

\footnotetext{
${ }^{25}$ Nurcholish Madjid, Cita-Cita Politie Istam Era Reformasi, Jakarta, Paramadina, 1999, hal. 3.

${ }^{26}$ Katherine C. Kolstad, Retorika Ketidukpuasan Islam:Analisis Alos Peristiwa Tanjung Priok, dalam Mark R. Woodward (Ed), Ialan Bam Islam, Memetakan Paradigma Mutakhir Islam di Indonesia, Bandung, Mizan, 1996, hal. 313.
} 
landasan hidup bersama dan bernegara. ${ }^{27}$ Landasan kesepakatan ini bertahan hingga masa modern sekarang. Apabila dilihat dari sisi perjuangannya, umat Islam kalah dan kekalahan ini menyimpan perasaan aspiratif psikologis yang akan terus berlangsung hingga masa yang akan datang.

Ternyata benar juga, tepatnya pada tahun 1955 uji coba perjuangan politik Islam mendapat momentumnya dengan memenangkan pemilu yang diwakili Partai Majlis Syura Muslimin Indonesia (Masyumi). Namun, lagi-lagi kemenangan tersebut tidak bernafas lama, karena kemudian dibubarkan oleh pemerintah Orde Lama yang dikomando Soekarno. ${ }^{28}$ Percobaan-percobaan perjuangan politik umat Islam, meskipun selalu kandas ternyata bukan semakin menyusut gerakannya, namun makin berkembang dalam bentuk dan dialektika yang beragam. Kaidah fiqh "apa yang tidak bisa dilakukan seluruhnya, jangan ditinggalkan seluruhnya", 29 nampak sangat relevan dalam mencermati perjuangan politik Islam di Indonesia.

Pada era baru, era reformasi sekarang, perjuangan politik Islam dengan segala tantangan perubahannya, makin tumbuh menggejala dalam scope yang lebih meluas. Gejala-gejala tumbuhnya kembali politik Islam setelah 30 tahun ditekan oleh penguasa Orde Baru memang seperti ditulis beberapa analis bukanlah hal yang bersifat terjadi begitu saja, namun juga memiliki akar jaringan hingga ke hulu Islam, seperti situasi politik yang terjadi Timur Tengah dan tekanan politik dan budaya Barat. Modernisasi dan sekularisasi yang ditabuh Barat dan Kristen telah menumbuhkan kecurigaan dan kompetisi memperoleh pengaruh yang kuat dicatat umat Islam. Hingga saat ini pula umat Islam menaruh sikap permusuhan dengan Barat. ${ }^{30}$ Negara-negara muslim banyak yang jatuh dan dikendalikan Barat. Mereka lemah karena situasi politik tidak menentu. Kelaparan, kemiskinan dan kebodohan tidak sulit ditemukan, karena memang telah menjadi pemandangan sehari-hari.

\footnotetext{
${ }^{27}$ Endang Saefuddin Anshari, The Jakarta Charter 1945, The Struggle for an Istamic Constitution in Indonesia, Malaysia, ABIM, 1979.

${ }^{28}$ Deliar Noer, Asas Tunggal Pancasila, Jakarta, Panjimas, 1982.

${ }^{29}$ Bunyi kaidah tersebut, "malayudraku kullubu la yudraku kullubu". A. Djazuli, Ilmu Figh Sebuab Pengantar, Bandung, Orba Shakti, 1997, hal. 21.

30William Montgomery Watt, Fundamentalisme Islam dan Modemitas, terj. T. Adnan Amal, Jakarta, RajaGrafindo Persada, 1997, hal. 200.
} 
Atas dasar argumen tersebut, tidak mengherankan jika gagasan-gagasan Barat seperti tentang negara-bangsa dan renaisannya masih dipandang sebagai ancaman kedua setelah Perang Salib. Beberapa persoalan inti tentang Islam konteks Indonesia, seperti dicatat Belveer Singh dan A. Munir Mulkan, berikut: ${ }^{31}$ pertama, problem internal umat Islam. Teori C. Geertz tentang tipologi santri, priyayi dan abangan, ${ }^{32}$ yang mengambarkan wujud nyata umat Islam Indonesia masih relevan dijadikan gambaran yang sesungguhnya. Kedua, adanya kompetisi dan pertikaian gagasan antara Islam liberal dan konservatif. Arus kelompok pertama lebih banyak melakukan kajian historis Islam seraya melakukan upaya-upaya kontekstualisasi Islam sesıai ruang dan waktu. Sementara yang kedua merupakan arus Islam yang kukuh pada teks dan keyakinan lama, sehingga menunjukan adanya kompetisi di antara dua kelompok secara bersebrangan.

Ketiga, peta sosial budaya kaum santri. Santri tidak bisa lagi terikat pada satu pilihan Islam, namun sudah leluasa untuk berafiliasi dengan organisasioraganisasi yang lebih terbuka sepcrti dilakukan olch kaum muda muslim perkotaan. Mercka nampak lebih aktif dan progresif merespons perkembangan baru. Kolaborasi dan "perkawinan" antara kelompok nasionalis dan Islamis misalnya, sudah sangat terbuka dan tidak tabu lagi. Keempat, munculnya tafsir baru generasi muda santri. Santri modern ini mulai berani melakukan kritik terhadap gagasan-gagasan klasik Islam. kaum muda santri ini secara aktif dan progresif melakukan apa yang discbutnya sebagai kelompok transformatif Islam. Gerakan kaum muda progresif ini bagaimanapun telah memberi andil terhadap tumbuhnya gerakan-gerakan politik kelompok Islam lainnya di Indonesia.

Pengaruh politik Islam yang sangat mengguncang dan mendapatkan momentumnya ialah kctika para Mullah Iran, sebuah negara mayoritas Syi'ah, berhasil menggulingkan pemerintahan pro Barat Syah melalui Revolusi tahun 1978. Kejadian inj jclas sangat ditakuti Barat, karena dianggap dapat memberi

\footnotetext{
"Belveer Singh \& A. Munir Mulkan, Jejaring Radikalisme Islam di Indonesia, Jejaj Sang Pengantin Bunuh Din, Yogyakarta, JB Publisher, 2012, hal. 86.

${ }^{32}$ Clifford Gecrtz, The Religion of Java, Chicago, The University of Chicago Press, 1976.
} 
inspirasi terhadap umat Islam dunia untuk melakukarı tindakan serupa. Ketakutan dan kekhawatiran Barat terhadap Islam sudah bukan lagi barang tersembunyi, namun sudah masuk pada piranti yang lebih lunak, yaitu lahirnya teori yang mengusung penghadapan Barat dengan Islam, seperti yang dilakukan Samuel P. Huntington dalam wrjud benturan budaya (the clash of civilization). ${ }^{33}$

Pengaruh-pengaruh eksternal terhadap tumbuhnya dan menguatnya politik Islam memang tidak bisa dianggap remeh. Paling tidak, pengaruh tersebut dapat memperkuat sementara keyakinan umat Islam untuk terus melakukan perjuangan (jibad) yang sudah lama tertanam dan isyaratnya ada dalam al-Quran..$^{34}$ Isyarat-isyarat tersebut kemudian dirumuskan oleh beberapa intelektual Islam menjadi landasan teori politik Islam. Sebagaian dari teori politik Islam ini sudah mafhum dan diketahui umat Islam, sehingga menjadi landasan pula dalam gerakan politik Islam masa kini.

Apabila mengacu pendapat Abul 'Ala Maududi, asas penting dalam teori politik Islam adalah tauhid. Seluruh Rasul dan Nabi Allah mempunyai tugas pokok untuk mengajarkan tauhid kepada seluruh umat manusia. Atas dasar ini pula, maka Tuhan dalam pandangan Maududi merupakan pemilik kekuasaan yang sebenarnya. ${ }^{35}$ Ia kemudian menurunkan asa sentral teori ini menjadi prinsiprinsip politik Islam, berikut: pertama, tidak ada seorang atau kelompok orang, bahkan seluruh penduduk suatu negara dapat melakukan klaim atau suverenitas (kedulatan). Hanya Tuhanlah pemegang kedaulatan dalam arti sebenarnya. Manusia hanya pelaksana kedaulatan tersebut.

Kedua, Tuhan adalah pencipta hukum yang sebenarnya (the real low-giver), sehingga Dia sajalah yang berhak membuat legislasi secara mutlak. Manusia diperkenankan membuat legislasi sepanjang legislasi tersebut tidak bertentangan dengan legislasi dasar yang berasal dari wahyu. ${ }^{36}$ Dua prinsip turunan dalam teori politik Islam ini, menunjukan bahwa Maudidi mendudukan posisi mnusia

\footnotetext{
${ }^{33}$ Samuel P. Huntington, Benturan Peradaban dan Masa Depan Politik Dunia, Jakarta, Qalam, 2002.

${ }^{34}$ Misalnya, QS, 22:77-78; QS, 5:35; QS, 49:15; QS, 25:52; dan QS, 9:86-88.

${ }^{35} \mathrm{Abul}$ 'Ala al-Maududi, Khilfah dan Kerajaan, Evaluasi Kritis Atas Sejarah Pemerintaban Islam, trj. M. al-Baqir, Bandung, Mizan, 1984, hal. 19.

${ }^{36}$ Abul 'Ala al-Maududi, Khiffah dan Kerajaan, .... Ibid, hal. 22.
} 
secara sentral sebagai wakil tuhan di bumi (khalifatullab fi al-Ard). Layaknya seorang wakil yang mewakili untuk melakukan tindakan sebagaimana amanat yang mewakilkan. Ia harus tunduk dan tidak boleh melakukan dan tidak melakukan di luar mandat yang mewakilkan (Tuhan).

Gagasan-gagasan Islam, termasuk gagasan tentang wajibnya mewujudkan masyarakat Islam, lebih mikronya 'negara Islam', diperlukan upaya penyebaran dan sosialisasi menyeluruh agar diketahui umat. Tindakan penyebaran dan sosialisasi nilai-nilai Islam ini secara normatif-konseptual disebut dengan da'wab. ${ }^{37}$ Tindakan dakwah dan upaya-upaya pendirian masyarakat Islam dengan jihad menjadi sangat integral meskipun jelas keduanya sangat berbeda, like to side of the same coin. Dakwah merupakan cara bagaimana Islam bisa disampaikan kepada umat dengan jihad. Sementara terwujudnya masyarakat Islam lebih merupakan target dan bukan tujuan utama.

Persoalan yang sering muncul ketika menyikapi cara dan tujuan dari Islam ini terkadang tumpang tindih. Sementara umat Islam menganggap bahwa pendirian sebuah organisasi dan lembaga Islam merupakan tujuan dan cita-cita Islam. Sementara lain ada yang menganggapnya hanya sebagai cara kecil saja, schingga umat Islam tidak diharuskan mendirikan masyarakat/negara Islam. Apalagi isyarat untuk tujuan tersebut tidak tersurat dalam al-Quran maupun hadits. Walaupun ada dalam pengalaman Nabi dan para sahabat empat sifatnya sangat kontekstual masa itu seperti dicatat dalam sejarah. ${ }^{38}$ Pengalaman Nabi dan para sahabatnya, karenanya tidak bersifat adhock, namun lebih bersifat historis. Konteks sekarang tentunya lebih komplek dari yang dialami Nabi dan karenanya dibutuhkan inovasi-inovasi baru berkaitan dengan pembentukan masyarakat Islam yang lebih kontekstual dengan jamannya.

Pemaknaan Islam oleh sebagaian umat Islam seperti gejalanya terjadi akhir-akhir ini, bolch jadi merupakan penangkapan Islam yang historis ini, kemudian dianggap dan diklaim sebagai Islam yang sebenarnya. Apalagi masyarakat umum masih mengganggap bahwa apa yang disebarkan oleh

\footnotetext{
${ }^{37}$ Ali Mahfoedz, Hidayat al-Mursyidin ila Thariq al-W'a'dzi wa al-Kbitabab, Mesir, dr alT'usham, tt, hal. 17.

${ }^{38}$ Marshal G.S. Hodgson, The Venture of Islam, Iman dan Sejarab dalam Peradaban Dunia Masa Klasik Islam, tri. Mulyadhi Kartanegara, Jakarta, Paramadina, 2002, hal. 277.
} 
penganut Islam "historis ini" sebagai Islam senyatanya karena ketidak-tahuan yang terlalu panjang dan kemalasan untuk mengkaji Islam lebih tajam lagi. Munculnya gerakan-gerakan Islam sparatis, formalis dan tekstualis, seperti diwakili oleh beberapa ormas Islam di Indonesia seperti gerakan Darul Islam, Komando Jihad, Laskar Jihad, Majlis Mujahidin, Hizbut Tahriri Indonesia, Jamaah Tablig, Ansharut Tauhid dan Front Pembela Umat Islam, jelas mewakili sebagaian dari spirit tersebut. ${ }^{39}$ Organisasi-organisasi Islam tersebut dengan lantang dan terbuka menyebarkan paham-paham Islam formal tersebut.

Belakangan gerakan organisasi-organisasi Islam tersebut sudah menyebar ke daerah-daerah dan memunculkan perjuangan dan perlawanan terhadap persoalan-persoalan moral dan sosial yang dianggap tidak sejalan dengan nilai-nilai Islam. Era reformasi dijadikan sebagai momentum penting untuk menyebarkan Islam dengan cara-cara yang lebih "bebas". Meskipun terkadang kebebasan tersebut dilakukan dengan cara yang dapat mengganggu kenyamanan orang lain yang memiliki paham berbeda dengan mereka. Gerakan Islam di daerah itu, di Tasikmalaya diwakili salah satunya oleh mereka yang mengklaim kelompoknya sebagai Brigade Tholiban ("barisan santri"). Brigade Tholiban atau BT, semula merupakan sebuah gerakan keprihatinan terhadap kondisi sosial dan moral di Kota Tasikmalaya yang makin hari makin mengkhawatirkan dalam pandangan mereka. Karenanya BT merupakan gerakan idiologi Islam khas Tasikmalaya.

Secara teologis, Islam adalah sistem nilai dan ajaran yang bersifat ilahiyah, dan karena itu sekaligus bersifat transenden. Namun secara sosiologis, ia merupakan fenomena peradaban, kultural dan realitas sosial dalam kehidupan manusia. Isalam dalam realitas bukan saja sebatas doktrin yang bersifat menjaman dan menjagat raya (universal), tetapi mengejawantah diri dalam institusi-institusi sosial yang dipengaruhi oleh situasi dan dinamika ruang dan

\footnotetext{
${ }^{39}$ Holk HAL. Dengel, Darul Islam-NII dan Kartosuviryo, Angan-Angan yang Gagal, Jakarta, Sinar Harapan, 1995. Khamami Zada, Islam Radikal Pergulatan Ormas-Omas Islam Garis Keras di Indonesia, Jakarta, Teraju, 2002. Taufik Adnan Amal \& Samsu Rizal Panggabean, Politik Syariat Istam dari Indonesia Hingga Nigeria, Jakarta, Pustaka Albet, 2004. Noorhaidi Hasan, Laskar Jihad, Islam, Militansi, dan Pencarian Identitas di Indonesia Pasca-Orde Baru, Jakarta, LP3ES, 2006. M. Zaki Mubarak, Genealogi Islam Radikal di Indonesia, Gerakan, Pemikiran dan Prospek Demokrasi, Jakarta, LP3ES, 2008.
} 
waktu. Islam sebagai sistem nilai dalam sejarahnya telah membantu para penganutnya untuk memahami realitas, kemudian mewrjud pada pola-pola pandangan dunia (weltanschaung) tertentu.

Dinamika historis Islam sejak masa Rosulullah hingga zaman modern sekarang telah mewujud dalam perjalanan hubungan yang saling mempengaruhi antara satu kekuatan dengan kekuatan lainnya, termasuk kekuatan politik Islam. Kejayaan Islam ternyata tidak mampu bertahan lebih lama karena berbagai perubahan yang terjadi dalam internal umat Islam. Pada dasawarsa 1970 dan tahun 1980, tuntutan politik Islam kembali nyaring disuarakan dengan beberapa faktor, mengcu A. Azra indiktornya, berikut: pertama, memburuknya posisi negara-negara muslim dalam konflik Utara-Selatan; kedua, perubahan sosial yang berlangsung amat cepat dengan akibat-akibatnya yang disruptif dalam masyarakat Islam; ketiga, krisi legitimasi dalam sistem-sistem politik berorientasi sekular. ${ }^{40}$

Semangat mengangkat kembali spirit gerakan Islam disuarkan Brigade Tholiban dengan kondisi yang mirip seperti dikemukakan di atas. Perubahan sosial yang terjadi di Tasikmalaya ditangkap BT sebagai bentuk kekhawatiran moral yang harus dilawan. Tumbuhnya pusat-pusat hiburan dan perbelanjaan dengan segala konsekuenasinya telah memicu kekhawatiran beberapa elemen tokoh santri untuk mengendalikannya. Namun demikian, cara dan pendekatan yang dilakukan BT cukup radikal dan cenderung tidak mengindahkan faktorfaktor institusi-institusi sosial yang melingkupinya.

Bentrokan kepentingan terjadi misalnya, BT diduga melindungi tokoh Jamaah Islamiyah $\Lambda$ bu Bakar Ba'asyir pada saat berkunjung ke Tasikmalaya. Ba'asyir diduga tcrlibat dalang intelektual maraknya tindakan teror di Indonesia, sehingga ia selalu menjadi incaran aparat berwenang. Massa BT terlibat pertikaian dengan aparat kepolisian karena dianggap melindungi Ba'asyir. Beberapa anggota BT hanya mengatakan bahwa kejadian tersebut hanyalah sebuah kesalah-pahaman.

\footnotetext{
${ }^{40}$ Azyumardi Azra, Pergolakan Politik Islam, dari Fundamentalisme, Modernisme bingga PosModemisme, Jakarta, Parmadina, 1996, hal. 18.
} 
Aktivitas politik praktis BT nampak kasat mata meskipun selalu dibantah para tokohnya. Ketika ditanya, adakah Taliban Tasikmalaya berencana melibatkan diri dalam panggung politik? "Saat ini tidak, tapi bila melihat kenyataan perilaku para penguasa yang korup dan banyak menzalimi rakyat serta menyimpang dari konsep Islam maka kemungkinan ke arah sana bisa saja terjadi". "Saat ini belum cukup kekuatan untuk melangkah lebih jauh, maka dengan dakwahlah kami menghimpun opini positif masyarakat terhadap misi thaliban untuk kemudian dijadikan sebuah energi guna mewujudkan pencapaian tujuan. Adakalanya dalam menghadapi sikap arogan penguasa pemerintahan terkendala oleh tokoh-tokoh agama munafik yang berbaris dibelakangnya, di mana mereka tidak bergeming meskipun melihat kenyataan adanya penyimpangan karena tentunya sudah terpasok keduniaan"."

Ketika disinggung mengenai kemungkinan adanya latihan fisik atau latihan militer yang dilakukan oleh thaliban, Ajengan Ruhanudin tokoh tholiban tersenyum hambar lalu mengatakan bahwa dalam kegiatannya tidak ada latihanlatihan khusus yang bermilisi. Kemudian saat diminta pandangannya terhadap "teroris" semisal yang dituduhkan kepada Jamaah Islamiah (JI) di Indonesia, ia juga tidak banyak berkomentar, kecuali menjelaskan tentang pemahaman dari pada konsep pergerakan yang dibawa oleh masing-masing kelompok. ${ }^{42}$

Thaliban Tasikmalaya seperti halnya gerakan Islam lainnya beroposisi dengan pihak pemerintahan, narnun dalam konsep pergerakannya lebih kepada sosial kemanusiaan. Munkin berbeda dengan Taliban di Afganistan ataupun gerakan Islam lainnya yang berorientasi kepada fadbail (amalan-amalan uatama ibadah), sehingga dalam pergerakannya terkesan radikal. Hal inipun bisa saja suatu waktu terjadi dengan Tholiban Tasikmalaya jika saja moralitas para penguasa sudah melampaui batas. Eksistensi Tholiban Tasikmalaya, sebuah organisasi pergerakan Islam yang saat ini tengah bergeliat di tengah keterpurukan moral manusia, apabila menyimak misinya, maka tidak menutup kemungkinan pergerakannya akan mewarnai performance politik di negeri ini.

\footnotetext{
${ }^{41}$ Nuansa Post,

${ }^{42}$ Membawa Aspirasi Masyarkat, Nuansa Post, 01 Januari 2012.
} 
Dakwah dan politik (bukumab) yang dilancarkan BT Tasikmalaya berpijak pada pandangan yang mirip dengan tugas-tugas kenabian (nubuwwab) yang tidak bisa dipisahkan satu dengan lainnya. Politik dalam bentuk tekanan terhadap penguasa lokal seperti bupati, walikota dan aparat kepolisian dalam menjalankan misinya dijadikan cara efektif yang berujung pada pengajuan aturan-aturan Islam agar dimasukan dalam peraturan daerah atau perda. Pengajuan perda Syariat Islam ini berjalan melenggang karena didukung hampir oleh semua fraksi DPRD baik di kota maupun di kabupaten, bahkan DPR RI melaluj wakilnya Asep Mausul.

Usaha BT berhasil, seperti Di Kota Tasikmalaya keluar Perda No. 12/2009 tentang: Pembangunan Tata Nilai Kemasyarakatan yang Berlandaskan agama Islam dan Norma-Norma Sosial Masyarakat Kota Tasikmalaya, setelah sebelumnya BT mendukung Syarif Hidayat sebagai walikota. Sementara di Kabupaten Tasikmalaya keluar Perda No.13/2003 dengan visi "Tasikmalaya yang religius/Islami sebagai kabupaten maju dan sejahtera serta kompetitif bidang agribisnis di Jawa Barat". ${ }^{43}$ Gagasan BT mendapat dukungan politisi sekaligus Bupati Tatang Farhanul Hakim. Keberhasilan ini jelas menunjukan bahwa gagasan dan gerakan idiologi BT mendapat dukungan luas publik, baik penguasa maupun masyarakat.

Dukungan BT terhadap walikota dan bupati dan tuntutan memasukan Perda syariat dalam peraturan formal, meminjam J.J. Rousseau, merupakan bentuk kontrak sosial (social contract) yang harus dipatuhi oleh kedua pihak. ${ }^{44}$ Penggolan Perda syariat juga merupakan akomodasi terhadap aspirasi masyarakat yang didukung para ajengan yang memiliki visi politik sekaligus modal politik dalam karinya ke depan. Masuknya beberapa ajengan ke dalam gedung DPRD dan DPR RI adalah fakta yang sulit dibantah.

Perda-perda Syariat tersetut jelas dapat dijadikan pijakan BT dalam melakukan aksinya memberantas segala bentuk yang dianggapnya kemungkaran, dan karena perda itu pula aksi dan gerakan BT mendapat bantuan dari aparat

\footnotetext{
4.7 Amin Muzakir, Politite Muslim dan Abmadiyah di Indonesia Pasca Soeharto: Kasus Cianjur dan Tasitemaluya, 2008. Makalah Internasional, Yayasan Percik. 2007 ,

${ }^{4}$ Jean Jacques Rousseau, Du Contract Social (Perjanjian Sosial), tri. Nino Cicero, Jakarta,
} 
kepolisian dalam menjalankan aksi-aksinya seperti disebut di muka. Aksi lainnya yang mendapat dukungan aparat, yaitu pemblokiran jalan setiap hari Jumat dan larangan terhadap perempuan yang ke luar di malam hari. Kasus wanita berjilbab Alifah yang karena keperluan keluarga datang ke Tasikmalaya kemudian dirazia dan digunduli merupakan tindakan nyata implementasi Perda syariat. $^{45}$

Dalam melaksanakan aksi-aksinya, terutama aksi penggalangan massa guna menekan pelaku pelanggaran tidak bisa dipungkiri memerlukan biaya tidak kecil. Para pimpinan mereka yang notabene para ajengan terpaksa harus mengeluarkan dana. Dari mana cara memperoleh dana tersebut dan bagaimana distribusinya menjadi hal penting untuk ditelusuri meskipun harus diakui bahwa penelusuran ini cukup rumit karena tidak dilakukan secara transparan ke publik. Namun, berdasar pada partisipasi dalam aksi-aksi mereka, penggalangan dana diperoleh dari sumber-sumber, seperti bupati dan walikota, kepolisian dan para anggota DPRD/DPR RI.

Oprasionalisasi Perda syariat dalam bentuk program pembangunan sarana ibadah, seperti masjid dan madrasah, plang-plang Asmaul Husna di setiap sudut jalan raya dan akomodasi para anggota BT, adalah di antara program implementasi Perda syariat yang padat dana. ${ }^{46}$ Proses implementasi Perda syariat ini, meminjam istilah media, membentuk apa yang disebut "proses komodifikasi simbol-simbol agama" yang ujung-ujungnya adalah target materi.

Sistematika gerakan BT yang bermula dari keprihatinan sosio-moral yang melanda Tasikmalaya berkembang ke ranah politik praktis dan berujung pada proyek-proyek yang menghasilkan pendapatan materi jelas merupakan dialektika sosial yang lumrah dan sulit dihindari. Proses sistematis gerakan idiologi sosial tersebut, pada akhirnya akan mengarah pada upaya-upaya perjuangan Islam yang lebih formalistik dan tekstualis. Argumen inilah yang memunculkan perlawanan terhadap gerakan seperti yang dilakukan BT oleh

${ }^{45}$ Taufik A. Amal \& Syamsu Rizal Panggabean, Politik Syariat Islam dari Indonesia bingga Nigeria, Jakarta, Pustaka Alvabet, 2004, hal. 92.

${ }^{46}$ Fakta-fakta tentang plang-plang, baliho dan slogan-slogan Islam tidak sulit diperoleh disepanang jalan dan sudut-sudut kota dan kampong di Tasikmalaya. 
beberapa kalangan Islam lainnya, seperti pemerintah, Jaringan Islam Liberal dan muslim moderat.

\section{E. Penutup}

Berdasar pada uraian di atas, gerakan sosial santri di Tasikmalaya melalui wadah Brigade Tholiban merupakan gerakan berbasis idiologi agama yang lahir karena keprihatinan terhadap maraknya pelanggaran moral yang menjamur di Tasikmalaya. Gerakan moral diimplementasikan dalam bentuk dakwah dengan sasaran utama para Pekerja Seks Komersial (PSK), bandar dan pelaku miras, geng motor, dan tekanan terhadap penguasa setempat.

BT tumbuh dan berkembang dimotori oleh para ajengan dan santri yang dikonsentrasikan di Pesantren Miftahul Huda dan beberapa pesantren di sekitarnya. Dalam aktivitasnya BT melakukan intensifikasi dakwah dengan penguatan penyebaran gagasan-gagasan Islam ke sentra-sentra jamaah pengajian yang diadakannya. Sementara aksi massa, sweeving dan demonstrasi dilakukan dan ditujukan terhadap para pclanggar "liar" seperti disebut di atas. Tekanan massa juga dilakukan dan ditujukan terhadap aparat pemerintah, seperti walikota, bupati dan kantor DPRD.

Tekanan-tekanan BT terhadap pemerintah membuahkan hasil dengan lahirnya Perda syariat. Perda ini merupakan landasan hukum bagi implementasi pelaksanaan syariat dan tindakan-tindakan sanksi yang melakukan pelanggaran. Perjuangan BT seperti memasukan nilai-nilai syariat Islam hingga menjadi Perda bisa berjalan cfektif karena beberapa kader BT aktif dalam politik praktis yang tersebar dalam partai-partai Islam. Masuknya kader-kader BT dalam partai politik jelas merupakan perkembangan orientasi gerakan yang semula hanya sebatas dakwah. Aktivitas politik inilah kemudian menjadi semacam "modal sosial" yang dapat menghasilkan dana bagi perluasan program-program Islamisasi Barisan Tholiban di Tasikmalaya khususnya. 


\section{DAFTAR PUSTAKA}

al-Maududi, Abul 'Ala. 1984. Kbilfab dan Kerajaan, Evaluasi Kritis Atas Sejarah Pemerintaban Islam, trj. M. al-Baqir, Bandung, Mizan.

Abu Zayd, Nasr Hamid. 1992. Al-Imam as-Syafi'i wa Ta'sis al-Aidulujiyah al. Wasathiyab, Cairo, Sina li an-Nasr.

Azra, Azyumardi. 1996. Pergolakan Politik Islam, dari Fundamentalisme, Modernisme bingga Post-Modernisme, Jakarta, Paramadina.

Ali, As'ad Said. 2012. Idiologi Gerakan Pasca Reformasi; Gerakan-Gerakan SosialPolitik dalam Tinjauan Ieologis, Jakarta, LP3ES.

Amal, Taufik Adnan \& Panggabean, Samsu Rizal. 2004. Politik Syariat Islam Dari Indonesia Hingga Nigeria, Jakarta, Pustaka Alvabet.

Aripudin, A. 2011. Tipologi Kejatuban Lembaga Pesantren, Studi Tiga Pesantren di Jawa Barat, Bandung, Fidkom-Lemlit Univ. Islam Negeri Sunan Gunung Djati.

Aripudin, A. 2013. Sosioogi Dakwah: Isu-Isu Kontemporer di Indonesia, Eandung, Rosdakarya.

Carvallo, Basco \& Dasrizal (Peny.). 1983. Aspirasi Umat Islam Indonesia, Jakarta, LEPPENAS.

Dhofier, Zamakhsyari. 2011. Tradisi Pesantren; Studi Tentang Pandangan Hiidup Kyai dan Visinya Membangun Masa Depan Indonesia, Edisi Revisi, Jakarta, LP3ES.

Esposito, John L. 2003. Unboly War, Teror Atas Nama Agama, trj. Safrudin Hasani, Yogyakarta, Ikon Teralitera.

Esposito, John L. 1994. Ancaman Islam Mitos atau Realitas? Menggugat Tesis Huntington, trj. Alwiyah \& MISSI, Bandung, Mizan.

Effendi, Bachtiar \& Prasetyo, Hendro (Ed). 1998. Radikalisme Agama, Jakarta, PPIM IAIN Jakarta.

Fromm, Erich. 2003. Akar Kekerasan Analisis Sosio-Psikologis Atas Watak Manusia, trj. Imam mutaqin, Yogyakarta, Pustaka Pelajar.

Geertz, Clifford. 1976. The Religion of Java, Chicago, The University of Chicago Press. 
Hodgson, Marshal G.S. 200ź. The Venture of Islam, Iman dan Sejarab dalam Peradaban Dunia Masa Klasik Islam, trj. Mulyadhi Kartanegara, Jakarta, Paramadina.

Hasani, Ismail \& Naipospos, Bonar T. 2010. Radikalisme Agama dan Implikasinya Terbadap Kebebasan Beragama/Berkeyakinan di Jabotabek dan Jawa Barat, Wajás Para Pembela Islam, Jakarta, Pustaka Masyarakat Petras.

Izutsu, Toshihiko. 1993. Konsep-Konsep Etika Religius dalam Qur'an, trj. A. Fahri Husain dkk, Yogyakarta, Tiara Wacana.

Jackson, Karl D. 1990. Kewibawaan Tradisional, Islam dan Pemberontakan; Karus Darul Islam Jawa Barat, Jakarta, Pustaka Utama Grafiti.

Madjid, Nurcholish. 1999. Cita-Cita Politik Islam Era Reformasi, Jakarta, Paramadina.

Mubarak, M. Zaki. 2008. Geneologi Islam Radikal di Indonesia Gerakan, Pemikiran dan Prospek Demokrasi, Jakarta, LP3ES.

Norris, Pippa \& Inglehart, Ronald. 2009. Sekularisasi Ditinjau Kembali; Agama dan Politik di Dunia Dewasa ini, trj. Ihsan Ali Fauzi \& Rizal Panggabean, Jakarta, Paramadina-Alvabet.

Qardhawi, Yusuf. 2010. Figh Jibad Sebuab Karya Monumental Teerlengkap Tentang Jibad Menurut al-Quran dan as-Sunnah, trj. Irfan M. Hakim dkk, Bandung, Mizan.

Rousseau, Jean Jacques. 2007. Du Contract Social (Perjanjian Sosial), trj. Nino Cicero, Jakarta, Transmedia Pustaka.

Sivan, Emmanuel. 1985. Radical Islam Medieval Theology and Moderm Politics, Yale University Press.

Singh, Belveer \& Mulkan, A. Munir. 2012. Jejaring Radikalisme Islam di Indonesia, Jejak Sang Pengantin Bunub Diri, Yogyakarta, JB Publisher.

Watt, William Montgomery. 1997. Fundamentalisme Islam dan' Modemitas, trj. Taufik Adnan Amal, Jakarta, RajaGrafindo Persada.

Woodward, Mark R. (Ed). 1998. Jalan Baru Islam Memetakan Paradigma Mutakbir Islam di Indonesia, trj. Ihsan Ali Fauzi, Bandung, Mizan.

Zada, Khamami. 2002. Islam Radikal Pergulatan Ormas-Ormas Islam di Indonesia, Jakarta-Bandung, Teraju. 


\section{Artikel/Internet/Makalah}

Aripudin, A. Akar Kekerasan, Republika, . Religiusitas Vs Sekularisme, Republika, . Dakwab Kontemporer, Republika,

Chandrasekaran, Rajiv. Indonesian Style Taliban Fights for Islamic Law, The Washington Post, Saturday, May 4, 2002.

Kabupaten Tasikmalaya, Tasik Selatan Media Online. Media Informasi Tasik Selatan. 29 Maret 2011.

Munawar, Spyan. Ormas Islam Sweeping Sarang Gang Motor Brigez, RMOL (Rakyat Merdeka Online)-Mingggu 18 Nopember 2012.

Masyarakat Tasikmalaya Selatan (Rampas) dan Brigade Tholiban Kembali Berdemo, PR Online 29 Maret 2011.

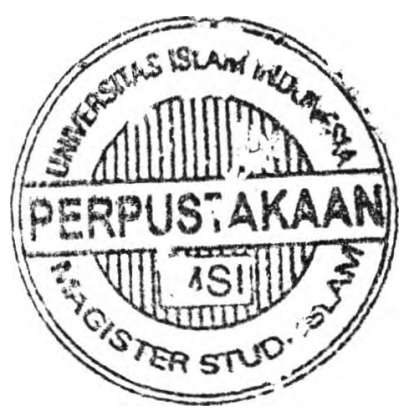

